\title{
Using Contextual Teaching and Learning (CTL) Strategy to Improve Students' Writing Skill
}

\author{
Gita Sri Jayanti ${ }^{1 *}$ and Yenni Rozimela ${ }^{2}$
}

\author{
${ }^{12}$ English Department, FBS Universitas Negeri Padang, Padang, Sumatra Barat 25131, Indonesia, Email: \\ *Corresponding author.Email: gitasrijayanti@gmail.com; yennirozi@gmail.com
}

\begin{abstract}
Nowadays, students have very little interest in writing which is so important to fulfill education requirements. Students do not only lack of vocabularies but also lack of ideas and motivation. It makes them feel difficult to write. This difficulty can be seen from their low writing scores, and their passiveness in learning activity. This is influenced by the inaccurate strategy that the teacher applies in writing lessons although several methods have been applied. CTL is one of the right strategies in overcoming students' difficulties in writing. CTL is a strategy to learning emphasizing the students' involvement in the full process, so they can find the material studied and relate them to the real-life situations encouraging them to apply the materials in life. This is Classroom Action Research (CAR). Observation, interview, and test writing were used to collect the data. The sample was the students grade VIII-4 of SMPN 3 Siabu in the academic year of 2020/2021.
\end{abstract}

Keywords: Contextual Teaching and Learning (CTL), Writing Skill

\section{INTRODUCTION}

Basically, English is one of the subjects that must be learned start from junior high school to university level in Indonesia. One of the four skills that should be developed in learning English in schools is writing is. It causes by writing, the students can express their ideas, thought, feeling, and give information to others. According to Nunan [1] writing is not an easy activity as it must make use of mental thinking in order to find, express, and organize ideas in paragraphs, making it easy for readers to understand.Agreeing with this, Weigle [2] states in writing the students should be able to deliver their thoughts, opinions, make the relationships between topics, correct grammar, good spelling, good mechanisms, vocabulary, show feelings and emotions in written form.Thus, they must transfer their ideas well and naturally in good and interesting writing. In achieving these goals, students must know the steps or procedures of how to write a text properly.

Based on the syllabus in the 2013 curriculum of grade VIII Junior High School in English, one of the scopes of learning English is understanding and making various short functional texts, monologues, and essays in the form of descriptive, procedures, recount, narrative, and reports by Depdiknas [3]. Students must master the types of text. Students are expecting to develop their writing skill to the fullest and know important things relate to writing.

Descriptive text is one kind of texts in writing. A descriptive text is about something, someone, or anywhere else in the description. Students can create everything related to the subject to learn the writing in order to make the text interesting. They can create a word with some creation when they write a text.

According to Gerot, Linda \&Wignell [4] descriptive text aims to give information. It describes particular things such as animals, people, and others. Moreover, Anderson and Anderson [5], adds the descriptive text refers to a specific person, place, or thing. Describing someone or something means writing descriptively. A descriptive text was also used to describe a topic's characteristics without including personal opinions. Kerafdescribed [6] in descriptive text the writer must transfer the images, feelings experienced by him or her to the reader. The writer tries to convey what they see and feel by picturing clearly in order to make the reader be able to imagine the object being described. It is the description of pets or a person that the writers know well. That idea explains that taking something that the writer knows well will help him or her to make the description more detailed.

Unfortunately, the researcher found several problems based on her personal experience as an English teacher at SMP Negeri 3 Siabu. The problems found were the students had low learning motivation especially in writing descriptive text. It is seen from their condition incapable of organizing their ideas, choosing or using appropriate vocabularies, arranging the words into good sentences, or implementing the language regulation. As a result, it gave an impact on the students' ability since only $50 \%$ of students get scores above the Minimum Criteria of Mastery Learning orKKM, $16.67 \%$ are limit to the KKM, and $33.33 \%$ are below the KKM or they are not successful. In this research predetermined KKM is 70 . It means that 
most students still think that writing is a complicated activity.

From the description above, one important factor that causes the students' low learning motivation in writing skill is the teaching and learning strategy. Clearly, this strategy impacts to learning becomes faster, easier, and and more transferable to new situations[7]. In teaching writing, the teacher must do many things. Several teaching and learning strategies are really needed for the teacher to support the teaching and learning process.

\subsection{Contextual Teaching and Learning (CTL)}

CTL is a strategy. It is a learning strategy linking the lessons with students' experiences in ever day life. Johnson [8] explained that CTL is a learning strategy, characterized by real experiences, real-world experiences, which students can gain their critical thinking, problemsolving skills, and knowledge. According to Baker, Hope, and Karandjeff [9] CTL actively build students' engagement and develop their learning and skills. This subject includes both knowledge and action. In addition, Sears [10] asserted that CTL encourages the students to participate in their learning and provides a specific framework for combining theory and practice of patterns. In addition, she points out that the CTL approach is designed to help students' understanding about the materials they learn in the classroom by connecting academic subjects to their personal, social and cultural situations.

CTL based learning problems can be used in individual and group learning processes. This strategy can also be applied in classroom environments and other types of learning. In addition, the Contextual Teaching and Learning (CTL) can promote students' abilities in writing skill [11]. CTL strategies are also essential to emphasize critical thinking, to recognize the teaching and education needs in a different context, to improve student learning motivation, and to use authentic assessments [12].

\subsection{Components of CTL in Teaching Writing Descriptive Text}

When students are able to construct their knowledge themselves, it would bring them to get a better understanding and long-term memory retention. When one makes the finding himself, he will never forget. Nurhadi [13] points out the seven main components of CTL in teaching writing descriptive text: (1) Constructivism is a component of CTL that focuses on humans that constructs everything in learning. Human in learning does not memorize materials but they construct. Sanjaya [14] states that constructivism is the process of building or organizing new knowledge in students' mindbased on their past event. Students are expected to be able and will be familiar with problem-solving and build their own knowledge by actively participating in the learning process. (2) Inquiry is a complex idea. It means that inquiry is a process of learning on search and through a systematic thought process. A number of facts the result of remembering but the result of discovering itself is called as intelligence knowledge. (3) Asking (Questioning) Learning meansprimarily asking and answering questions. Asking questions reflects the individual curiosity while answering questions reflects someone's thinking ability. (4) Learning
Community. Based on the concept of a learning community in CTL, learning outcomes is obtained through collaboration with others. This collaboration has various forms, both in formal study groups and in an environment that occurs naturally. (5) Modeling refers to the process of learning by showing a thing as a model that every student can imitate. Its process is not limited to teachers, but the students who have the ability can also do that. (6)Reflection refers to a way of thinking about the present and the past. Itresponds to events, activities, or experiences that have just been received. It is a process of analyzing, reviewing, responding to the learning processes. (7) Authentic Assessment refers to a process to collect information about the student learning progress.

\subsection{The strategies of CTL}

There are five strategies in the CTL known as REACT. According to Crawford [15] REACT strategies in the CTL can help and the students' writing descriptive text to improve their learning. These strategies are described by Crowford as follows: (1) Relating is learning within the setting of someone's encounters or previous information. Instructors utilize relating when they connect a modern theory to a thing totally commonplace to understudies, in this way interfacing what understudies as of now know to the modern data. When the interface is fruitful, the understudy picks up nearly moment understanding. In brief teacher will leads and empower understudies to relate what they are learning to a real-life encounter. (2) Experiencing. In some conditions in the relating stage, students do not have background knowledgeor experience. However, experience takes place inside the classroom to overcome the obstacle and construct new knowledge. It is known as experience. It can be defined as learning by doing. It has the parts: exploration, discovery, and invention. (3) Applying is learning by putting the concept to use. He also proposes that applying is a strategy of contextual teaching and learning developing a deeper sense of meaning a learning reason. (4) Cooperating is learning in the context of sharing knowledge. It is also the way students responding, and communicating in process of learning. Other students support someone's understanding. Students are confident and can ask questions without nervousness. When working through peers in a small group. (5) Transferring. Teachers assign big varieties of the task to facilitate learning for understanding after students pass through relating, experiencing, applying, and cooperating. Students who learn with transferring use knowledge in a new context or novel situationthat have not been covered in class.

Based on the definition and components of CTL, the researcher constructs the REACT strategy of teaching writing descriptive text. The researcher conducts the strategy of teaching writing descriptive text that includes components of CTL (questioning, constructivism, learning society, inquiry, reflection, modeling, and authentic assessment).

\section{METHOD}

This is a Classroom Action Research (CAR). According to Stringer [16], CAR functions to provide educational practitioners with new knowledge and resolve the essential classroom problems. Mettetal [17] also adds 
that CAR is a method of finding out the best works in the classroom and improving student learning.

In this CAR the spiral model was used [18].Plan, action, observation, and reflection are the four steps of spiral model.

Figure 1. The Procedure of Classroom Action Research

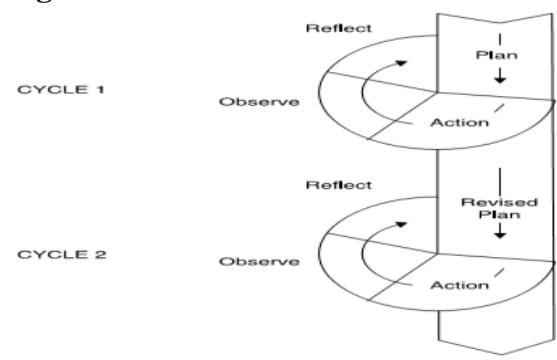

Figure 1 show the procedure of CAR consisting of two cycles. Each cycle consisted of four meetings with a test at the end of each cycle.
The population of this study was 30 students grade VIII-4 of SMPN 3 Siabu with a sample of the eighth. According to Arikunto [19],an instrument is a kind of tool to collect the data during research. The instruments used in this study were observation, interview, and test writing. Classroom observation was usefulto observe teacher and students' activities during the learning process. The interview was conducted to know the student's feeling and opinion about using CTL in teaching writing. Moreover, test writing wasto know the improvement of the students' ability in writing descriptive text.

\section{RESULTS AND DISCUSSIONS}

The teaching and learning process had two cycles: cycle I and cycle II. Every cycle had four meetings. The general procedures of this research can be seen below:

Table 1.Procedures of Teaching and learning process Using CTL

\begin{tabular}{|c|c|c|c|}
\hline NO & $\begin{array}{l}\text { Strategies of } \\
\text { CTL }\end{array}$ & $\begin{array}{l}\text { Components of } \\
\text { CTL }\end{array}$ & Activities \\
\hline 1. & Relating & Constructivism & $\begin{array}{l}\text { - The teacher stimulates students to think and relate the material to their } \\
\text { knowledge. }\end{array}$ \\
\hline \multirow[t]{4}{*}{2.} & \multirow[t]{4}{*}{ Experiencing } & \multirow[t]{3}{*}{ Inquiry } & - The teacher gives examples of problems in their daily lives. \\
\hline & & & $\begin{array}{l}\text { - The teacher stimulates students to think and relate the material to their } \\
\text { experiencing. }\end{array}$ \\
\hline & & & $\begin{array}{l}\text { - The students are given the chance to read and to find information from the } \\
\text { text by themselves. }\end{array}$ \\
\hline & & Questioning & $\begin{array}{l}\text { - The teacher stimulates students to ask questions and give ideas for } \\
\text { materials they often encounter in their environment. }\end{array}$ \\
\hline \multirow[t]{3}{*}{3.} & \multirow[t]{3}{*}{ Applying } & \multirow[t]{3}{*}{ Modeling } & $\begin{array}{l}\text { - The teacher gives the model of descriptive and recount text to the students. } \\
\text { The model should be in an interesting performance, can be colorful paper, } \\
\text { and use picture or nice writing. }\end{array}$ \\
\hline & & & - The teacher reads the model of descriptive orally \\
\hline & & & - The students are asked to listen carefully \\
\hline \multirow[t]{6}{*}{4.} & \multirow[t]{6}{*}{ Cooperating } & \multirow[t]{6}{*}{$\begin{array}{l}\text { Learning } \\
\text { community }\end{array}$} & $\begin{array}{l}\text { - The teacher explains what they are going to do for this learning, they will } \\
\text { describe the picture, tell their experience and then they write a description } \\
\text { and information in the text. }\end{array}$ \\
\hline & & & $\begin{array}{l}\text { - The students will be divided into six groups, because there are } 30 \text { students } \\
\text { and each group consists of five students. The teacher divides them to telling } \\
\text { the numbers from one until six. }\end{array}$ \\
\hline & & & $\begin{array}{l}\text { - The teacher gives the problems for students relate to the material. Teacher } \\
\text { will distribute the picture of mystery thing to each of group, then, do not let } \\
\text { the other group to know the picture of mystery thing. }\end{array}$ \\
\hline & & & - The students are asked to describe the mystery thing in their group. \\
\hline & & & $\begin{array}{l}\text { - The teacher makes meaningful connection; help the students } \\
\text { communicatively and friendly. The teacher guides the students in } \\
\text { describing the things, then, avoid the description to word that close related } \\
\text { to thing. }\end{array}$ \\
\hline & & & $\begin{array}{l}\text { - The teacher monitors the students in doing task; the teacher should be } \\
\text { friendly and help students who get the difficulties. }\end{array}$ \\
\hline \multirow[t]{4}{*}{5.} & \multirow[t]{4}{*}{ Transferring } & \multirow[t]{2}{*}{ Reflection } & $\begin{array}{l}\text { - Next, the teacher reflects the learning process. The teacher gives comment } \\
\text { to the students' process in learning, start from describing thing until the } \\
\text { guessing part. The teacher should give reward or suggestion and spirit to } \\
\text { the students. }\end{array}$ \\
\hline & & & $\begin{array}{l}\text { - Then, the studentsar asked to write the descriptive and recount text based } \\
\text { on the description of the thing for each group, and they can create their } \\
\text { writing with nice creation of them. }\end{array}$ \\
\hline & & \multirow[t]{2}{*}{$\begin{array}{l}\text { Authentic } \\
\text { assessment }\end{array}$} & $\begin{array}{l}\text { - After learning writing descriptive in learning society, the students are asked } \\
\text { to produce the descriptive individually based on the things given by } \\
\text { teacher. Students can reach standard individually. }\end{array}$ \\
\hline & & & $\begin{array}{l}\text { - Teachers will use authentic assessment in those teaching writing descriptive } \\
\text { text to evaluate the students' learning process. }\end{array}$ \\
\hline
\end{tabular}


These procedures are used in cycle I and cycle II.

Cycle I

In this phase, all the activities content each step that do as detail as possible. The activities are preparing material of the descriptive text. The materials relate to the topic and the student's background. In the first cycle the topic of Descriptive text is about Flora and Fauna, and second cycle the topic of Descriptive text is about Family. a) Plan

Based on the students writing problems, the researcher and collaborator planned to give solution. It was made the teaching writing better and improves students' achievement. The solution was using Contextual Teaching and Learning (CTL) as the strategy to teaching writing. This strategy was expected to help students improve their writing skills.

b) Action

The action stage was done based on the lesson plan that had been prepared in the planning stage. For the first cycle, the researcher has done four meetings. Every meeting has duration of $2 \times 40$ minutes.

c) Observation

The observation toward teaching and learning activities through the instrument used was conducted by the researcher and collaborator. The students' responses, participation, and achievements found during the teaching and learning process were observed. Sometimes, some students' opinions about the process of teaching and learning by using Contextual Teaching and Learning strategies were also asked. Yet, the researcher still could not run the activities well. From the students' side, it was seen that the students still got confused with the activities and they still cannot express their ideas naturally in writing descriptive text.

Besides task results that was gained in every meeting, the data were also taken from the writing test result at cycle I as shown in table 2.

Table 2. The result of the students' writing Test in cycle I

\begin{tabular}{|c|c|c|c|c|}
\hline No & Score & $\begin{array}{c}\text { Fre- } \\
\text { quency }\end{array}$ & $\begin{array}{c}\text { Percen- } \\
\text { tage }\end{array}$ & Criteria \\
\hline 1 & 50 & 1 & $3 \%$ & INCOMPLETE \\
\hline 2 & 55 & 2 & $7 \%$ & INCOMPLETE \\
\hline 3 & 60 & 3 & $10 \%$ & INCOMPLETE \\
\hline 4 & 65 & 4 & $13 \%$ & INCOMPLETE \\
\hline 5 & 70 & 9 & $30 \%$ & COMPLETE \\
\hline 6 & 72 & 3 & $10 \%$ & COMPLETE \\
\hline 7 & 75 & 2 & $7 \%$ & COMPLETE \\
\hline 8 & 78 & 3 & $10 \%$ & COMPLETE \\
\hline 9 & 80 & 2 & $7 \%$ & COMPLETE \\
\hline 10 & 85 & 1 & $3 \%$ & COMPLETE \\
\hline & 2075 & 30 & $100 \%$ & \\
\hline
\end{tabular}

\section{d) Reflection}

After collecting the data, the data of the teaching and learning process were analyzed.By referring to the data analysis on the cycle I, there were some weaknesses found in using CTL strategy. Therefore, the researcher and collaborator continued the research to the next cycle which was determining better improvement for the students' writing skill.
Cycle II

a) Plan

The researcher and collaborator discussed, evaluated and revised some teaching and learning activities. The revising plans more focused on the problems and weaknesses found in the cycle I. Then, they were needed to be solved in this cycle.

b) Action

The action if cycle II was also same as the previous cycle. The cycle dealt with four meetings. The topic given to the students was familiar for them, which was about Family. In cycle II the researcher deepened the students' writing skill by providing writing task. The students were asked to write the text by using the strategy without teacher support and by them.

c) Observation

The observation toward teaching and learning activities through the instrument used were conducted by the researcher and collaborator. The students' responses, participation, and achievements found during the teaching and learning process were observed. Then, the students' responses with classroom activities were also observed. Through the activities, the students were more active in the class and involved in learning activities by asking some questions to the teacher. Furthermore, the students' writing test at cycle II highlighted the significant improvement as shown in table 3.

Table 3. The result of the students' writing Test in cycle II

\begin{tabular}{|c|c|c|c|c|}
\hline No & Score & $\begin{array}{c}\text { Fre } \\
\text { quency }\end{array}$ & $\begin{array}{c}\text { Percen } \\
\text { tage }\end{array}$ & Criteria \\
\hline 1 & 60 & 1 & $3 \%$ & INCOMPLETE \\
\hline 2 & 65 & 2 & $7 \%$ & INCOMPLETE \\
\hline 3 & 70 & 2 & $7 \%$ & COMPLETE \\
\hline 4 & 72 & 4 & $13 \%$ & COMPLETE \\
\hline 5 & 75 & 5 & $17 \%$ & COMPLETE \\
\hline 6 & 78 & 5 & $17 \%$ & COMPLETE \\
\hline 7 & 80 & 4 & $13 \%$ & COMPLETE \\
\hline 8 & 82 & 3 & $10 \%$ & COMPLETE \\
\hline 9 & 85 & 2 & $7 \%$ & COMPLETE \\
\hline 10 & 90 & 2 & $7 \%$ & COMPLETE \\
\hline \multicolumn{2}{|c}{ Total } & 30 & $100 \%$ & \\
\hline
\end{tabular}

\section{CONCLUSION}

This study give significant new knowledge about the extent of using CTL strategy in improving the students' writing skill. Observations, students' interviews, and test writing were the instruments to collect the data. It was found that the mean scores between cycle I and cycle II were signifant difference. Therefore, the CTL strategy can be implemented in teaching writing descriptive text. Relating, experiencing, applying, cooperating, and transferringwere the teaching strategies in this study. In addition, to assess the students' writing, authentic material was also used. Thus, the influence of CTL strategy on others students' learning skill can also be explored by other researchers.

\section{ACKNOWLEDGMENT}

I would like to thanks to Allah S.W.T who has given His grace and gifts to me. Finally I finished wrtiting this paper. And I am deeply indebted to my advisor Prof. Yenni 
RozimelaM.Ed, Ph.D, for warm support, inspiration, and thoughtful guidance. Then,I would like to express the deepest appreciation to my beloved family and my friends who have given me support, prayer, and motivation. This paper is far from being perfect, but it is expected that it will be useful not only for the researcher, but also for the readers. For this reason, suggestions and critics are really welcomed. Thank you.

\section{REFERENCES}

[1] Nunan, David. 2005. Task Based Language Teaching. Cambridge: Cambridge University Press

[2] Weigle, Sara Cushing, 2002. Assessing Writing.Cambridge University Press. New York

[3] Depdiknas. 2005. MateriPelatihanIntegrasi: PembelajaranKontestual (CTL). Jakarta: Depdiknas

[4] Gerot, Linda \& Peter Wignell. 1994. Making Sense of Functional Grammar. Sydney: Antipodean Educational Enterprise.

[5] Anderson and K. Anderson, 2003. Text Types in English 1, Australia: Macmillan.

[6] Keraf, G. 2000. EksposisidanDeskripsi. Jakarta. Gramedia.

[7] Oxford. R. 1990. Language Learning Strategies: What every teacher should know. University of Alabama.Botson.Heinle\&Heinle Publication.

[8] Johnson, Elaine 2002. DiterjemahkanolehAlwasilah, Chaedar. 2014. Contextual Teaching \& Learning. PenerbitMizan. Bandung

[9] Baker, E. D., Hope, L., \&Karandjeff, K. (2009). Contextualized Teaching \& Learning: A Faculty Primer.A Review of Literature and Faculty Practices with Implications for California Community College Practitioners.Academic Senate for California Community Colleges: California.

[10] SEARS, S., 2003. Introduction to Contextual Teaching and Learning the Phi Delta Kappa Educational Foundation,Bloomington, Indiana

[11] Satriani, I., Emilia, E., \&Gunawan, M. H. (2012). Contextual teaching and learning approach to teaching writing. Indonesian Journal of Applied Linguistics, 2(1), 10-22. https://doi.org/10.17509/ijal.v2i1.70

[12] Blanchard, H. D. 2007. Teaching by Principles: An Interactive Approach to Language Pedagogy. (2nd ed.). New York: Longman

[13] Nurhadi.2003. PembelajaranKontekstual (Contextual Teaching and Learning/CTL). Malang. UniversitiasNegeri Malang.

[14] Sanjaya, Wina, 2013. StrategiPembelajaran. Kencana. Bandung.

[15] CRAWFORD, M.L., 2001. Teaching contextually: Cooperating, and Transferring). Journal of English and Research, rationale, and techniques for improving student motivation and achievement in mathematics and science. Texas: CORD
[16] Stringer, E. T. (2007). Action Research, 3rd Edition. United States of America: Curtin University of Technology, Australia. Sage Publications.

[17] Mettetal, G. (2002). The What, Why and How of Classroom Action Research.Indiana University Press(10), 9-39. Scholarly Journals 1

[18] Kemmis,S and Robin, Mc Taggart. 1998. The Action Research Planner. Victoria: Daeken University.

[19]Arikunto, Suharsimi, 2014 ProsedurPenelitianSuatuPendekatanPraktik. RinekaCipta. Jakarta 